\title{
Cyclic adenine nucleotide levels in lymphocytes from patients with systemic sclerosis: efficiency of prostaglandin infusions
}

\author{
IREN B. KOVACS \\ M.D., Ph.D. \\ J. D. T. KIRBY \\ M.R.C.P.
}

\author{
PAUline M. DOWD \\ B.Sc., M.R.C.P. \\ PAUL TURNER \\ M.D., B.Sc., F.R.C.P.
}

Departments of Dermatology and Clinical Pharmacology, St Bartholomew's Hospital, London EC1A 7BE

\section{Summary}

Basal intracellular cAMP levels of lymphocytes from patients with systemic sclerosis, all suffering from Raynaud's phenomenon, were significantly lower than those obtained from normal controls. Moreover, the cAMP response to isoprenaline of these patients' lymphocytes was inhibited. Intravenous infusion of prostaglandins $\left(E_{1}\right.$ and $\left.I_{2}\right)$ restored the basal levels and greatly improved the responsiveness of the cells to isoprenaline stimulation.

KEY WORDS: systemic sclerosis, Raynaud's phenomenon, prostaglandins, immune response, lymphocytes.

\section{Introduction}

In a previous study (Kirby et al., 1980), the low intracellular levels of cyclic adenosine $3^{\prime}, 5^{\prime}$-monophosphate (cAMP) of lymphocytes measured in patients with systemic sclerosis (SS) showed a striking increase in response to isoprenaline after infusion of the patients with prostacyclin $\left(\mathrm{PGI}_{2}\right)$. $\mathrm{PGI}_{2}$ infusion alone did not, however, increase the low basal lymphocyte cAMP levels. In a further attempt to monitor the observed long-term beneficial effects of infusions of prostaglandin $\mathrm{E}_{1}\left(\mathrm{PGE}_{\mathrm{l}}\right)$ (Martin et al., 1980) and PGI (Dowd et al., 1982) by biochemical parameters, cAMP levels were measured before, and immediately after, infusion of $\mathrm{PGE}_{1}$ and $\mathrm{PGI}_{2}$ in patients with systemic sclerosis who all had Raynaud's phenomenon.

\section{Patients and methods}

Patients were compared with healthy Caucasian subjects, age and sex matched. Basal and isoprenaline stimulated lymphocyte cAMP levels were measured, first, to establish the difference between the SS patients and controls, and then, in a separate study in the patients, before and after the $72 \mathrm{hr}$ infusion of $\mathrm{PGE}_{1}$ (in doses up to $12 \mathrm{ng} / \mathrm{kg} / \mathrm{min}$ ) and $\mathrm{PGI}_{2}$ (in doses up to $7.5 \mathrm{ng} / \mathrm{kg} / \mathrm{min}$ ). $\mathrm{PGI}_{2}$ (lyophilized, supplied by Burroughs Wellcome) was reconstituted with glycine buffer (pH 10.5), $10 \mathrm{ml}$ of buffer per 0.5

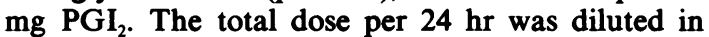
normal saline $(210 \mathrm{ml})$ with the addition of $40 \mathrm{ml}$ glycine buffer so that $250 \mathrm{ml}$ of $\mathrm{PGI}_{2}$ solution was infused over $24 \mathrm{hr}$. Peripheral blood was drawn with heparin as anticoagulant and lymphocytes were isolated by the Ficoll-Hypaque density gradient technique (Böyum, 1968). Lymphocytes $\left(1 \times 10^{6}\right.$ cells) were incubated in Hank's balanced salt solution without and with $\mathrm{D}, \mathrm{L}$-isoprenaline. Theophylline $\left(10^{-2} \mathrm{~mol} / \mathrm{l}\right)$ was added to all tubes in order to inhibit phosphodiesterase activity. cAMP was measured by radio-immunoassay, using the New England Nuclear kits.

\section{Results}

Basal levels of intracellular cAMP and the increase after isoprenaline stimulation are shown in Table 1. In all cases, good correlation $(P<0.01)$ was found between the intracellular cAMP content and the concentration of the agonist. Basal cAMP levels of lymphocytes from SS patients were significantly lower than those from age-matched, normal controls. The cAMP response curve to isoprenaline stimulation was also significantly lower $(P<0.05)$ than that measured in lymphocytes of normal subjects and was not parallel to it (Table 1). In a separate study (Table 2), $\mathrm{PGE}_{1}$ infusion significantly increased the basal cAMP levels and increased cAMP response to isoprenaline stimulation. $\mathbf{P G I}_{2}$ infusion also greatly increased the basal cAMP content of the cells, resulting in a level two- or three-fold higher than the corresponding pre-treatment values. The response of 
TABLE 1. Lymphocyte cAMP levels of normal subjects and patients with systemic sclerosis (SS)

\begin{tabular}{|c|c|c|c|c|c|c|}
\hline & \multirow[b]{3}{*}{$n$} & \multicolumn{5}{|c|}{ cAMP (pmole per $10^{6}$ cells) (mean \pm s.e.m.) } \\
\hline & & \multirow[b]{2}{*}{ Basal } & \multicolumn{4}{|c|}{ With isoprenaline (mol/1) } \\
\hline & & & $10^{-7}$ & $10^{-6}$ & $10^{-5}$ & $10^{-4}$ \\
\hline Normal subjects & 9 & $\begin{array}{r}33.6 \\
\pm 4.3\end{array}$ & $\begin{array}{r}39 \cdot 1 \\
\pm 5.8\end{array}$ & $\begin{array}{r}49.7 \\
\pm 5.9\end{array}$ & $\begin{array}{r}61 \cdot 1 \\
\pm 6.4\end{array}$ & $\begin{array}{r}76 \cdot 2 \\
\pm 6.4\end{array}$ \\
\hline SS patients & 9 & $\begin{array}{l}18.0^{*} \\
\pm 2.5\end{array}$ & $\begin{array}{r}26.3 \\
\pm 4.4\end{array}$ & $\begin{array}{r}35.4 \\
\pm 4.7\end{array}$ & $\begin{array}{r}42 \cdot 1 \\
\pm 5 \cdot 3\end{array}$ & $\begin{array}{r}49.3 \\
\pm 4.8\end{array}$ \\
\hline
\end{tabular}

*Basal levels: controls $v$. patients, $P<0 \cdot 01$.

TABLE 2. Alteration of lymphocyte cAMP levels with prostaglandin infusions in patients with systemic sclerosis

\begin{tabular}{|c|c|c|c|c|c|c|}
\hline & \multirow[b]{3}{*}{$n$} & \multicolumn{5}{|c|}{ cAMP (pmole per $10^{\circ}$ cells) (mean \pm s.e.m.) } \\
\hline & & \multirow[b]{2}{*}{ Basal } & \multicolumn{4}{|c|}{ With isoprenaline (mol/l) } \\
\hline & & & $10^{-7}$ & $10^{-6}$ & $10^{-5}$ & $10^{-4}$ \\
\hline Before $P G E_{1}$ & 5 & $\begin{array}{r}16.1 \\
\pm 3.4\end{array}$ & $\begin{array}{r}23.9 \\
\pm 4.2\end{array}$ & $\begin{array}{r}32.7 \\
\pm 5 \cdot 1\end{array}$ & $\begin{array}{r}41 \cdot 5 \\
\pm 5 \cdot 2\end{array}$ & $\begin{array}{r}51.6 \\
\pm 4.2\end{array}$ \\
\hline After PGE & 5 & $\begin{aligned} & 51.2 \dagger \\
\pm & 5.8\end{aligned}$ & $\begin{array}{r}54 \cdot 2 \\
\pm 2 \cdot 3\end{array}$ & $\begin{array}{r}72 \cdot 1 \\
\pm 4 \cdot 7\end{array}$ & $\begin{array}{r}92.2 \\
\pm 4.9\end{array}$ & $\begin{array}{r}113.1 \\
\pm 11.4\end{array}$ \\
\hline Before $\mathrm{PGI}_{2}$ & 6 & $\begin{array}{r}20.1 \\
\pm 2.7\end{array}$ & $\begin{array}{r}29.1 \\
\pm 6.1\end{array}$ & $\begin{array}{r}37.4 \\
\pm 6.3\end{array}$ & $\begin{array}{r}40.6 \\
\pm 5.9\end{array}$ & $\begin{array}{r}45.9 \\
\pm 6.6\end{array}$ \\
\hline After $\mathrm{PGI}_{2}$ & 6 & $\begin{aligned} & 65 \cdot 0^{*} \\
\pm & 10.8\end{aligned}$ & $\begin{array}{r}75.8 \\
\pm 10.5\end{array}$ & $\begin{array}{r}94.9 \\
\pm 15.4\end{array}$ & $\begin{array}{r}111 \cdot 1 \\
\pm 21 \cdot 7\end{array}$ & $\begin{array}{r}125 \cdot 2 \\
\pm 22.0\end{array}$ \\
\hline
\end{tabular}

Basal levels: before $v$. after infusion, ${ }^{*} P<0.01,+P<0.001$.

Differences between the slopes of isoprenaline stimulation: before $v$. after $\mathrm{PGE}_{1}, P<0.01$; before $v$. after $\mathrm{PGI}_{2}, P<0.05$.

cells to isoprenaline stimulation was also significantly increased as compared to the pre-treatment values.

\section{Discussion}

These results confirm and extent our earlier observations (Kirby et al., 1980) in which we showed that lymphocyte responsiveness to isoprenaline was reduced in patients with SS. In that study, there was a tendency for basal cAMP levels to be reduced, but this was not significant. The present study now demonstrates this to a significant degree. Our findings, that both the basal cAMP levels as well as the increase in response to stimulation are significantly lower in lymphocytes from patients with SS than in cells from normal healthy subjects, can be regarded as evidence for probable altered function of these cells. Formerly, cAMP was considered as a negative regulator of the proliferative response of cells to mitogen, but recent studies have suggested a positive regulatory role of the increase in cAMP, and, in addition, endogenous prostaglandins were also thought to play an important role (Wang, Sheppard and Foden, 1978). If endogenous prostaglandins are involved in the immune response then the efficiency $\overrightarrow{\bar{B}}$ of prostaglandin infusions in restoring basal cAMP levels which we have demonstrated, may indicate a deficiency of their synthesis in lymphocytes or their altered metabolism in our patients. This could occur 3 as a basic defect or follow alteration of cellular receptors by a pathogen or circulating immune 3 . complexes. This awaits further study.

The part played by altered immune function in the pathogenesis of SS is not clear. There is, however, evidence for disturbance of lymphocyte activity from? many previous studies. Most patients have anti- $\frac{}{0}$ nuclear antibodies present in the sera when a suitable range of substrate tissue is used to detect their $\tilde{N}$ presence (Bernstein, Steigerwald and Tan, 1982). N Alteration of B cell function is manifest also by increased immuno-globulin production across the $\omega$ range of clinical presentations of this disease. This in turn may reflect altered $\mathrm{T}$ cell suppressor function ${ }^{\circ}$ (Inoshita et al., 1981). In this study, peripheral blood $\mathbb{D}$ was used which contains predominantly $\mathrm{T}$ lympho-: cytes, but we have been unable at this stage of our work to identify cell types in the individual samples $\underset{\mathbb{D}}{\mathbb{D}}$ and this is to be the subject of further prospective $\frac{?}{\mathbb{D}}$ 
studies which will also include patients with Raynaud's phenomenon who do not have other evidence of SS. The results of the study, however, suggest that both cell types might be affected in our subjects, and further support a role for immune disturbance as an important factor in the pathomechanism of the disease.

The increased cAMP response to isoprenaline produced by $\mathrm{PGI}_{2}$ infusion confirms our earlier observation (Kirby et al., 1980), and we have now shown that $\mathrm{PGE}_{1}$ produces a similar effect, consistent with beneficial clinical effects shown by Martin et al. (1980). Similar studies in age and sex matched controls after prostaglandin infusion will be required to demonstrate whether or not lymphocyte responsiveness in our patients has returned to normal. However, the present results suggest that these prostaglandins, or perhaps more convenient orally active analogues, may prove of therapeutic value in patients with this condition.

Dr I. B. Kovacs is in receipt of a grant from the North-East Thames Regional Health Authority.

\section{References}

Berstein, R.M., Steigerwald, J.C. \& TAN, E.M. (1982) Association of antinuclear and antinucleolar antibodies in progressive systemic sclerosis. Clinical and Experimental Immunology, 48, 43.

BÖYUM, A. (1968) Isolation of mononuclear cells and granulocytes from human blood. Scandinavian Journal of Clinical Investigation, 21 (Suppl. 97), 77.

DowD, P.M., MARTIN, M.F.R., Cook, E.D., BowCock, S.A., Jones, R., DIEPPE, P.A. \& KIRBY, J.D.T. (1982) Treatment of Raynaud's phenomenon by intravenous infusion of prostacyclin. British Journal of Dermatology, 106, 81 .

Inoshita, T., Whiteside, T.L., Rodnan, G.P. \& TAYloR, F.H. (1981) Abnormalities of T lymphocyte subsets in patients with progressive systemic sclerosis. Journal of Laboratory and Clinical Medicine, 97,264

Kirby, J.D.T., Lima, D.R.A., Dowd, P.M., KILfEATHer, S. \& TURNeR, P. (1980) Prostacyclin increases cyclic nucleotide responsiveness of lymphocytes from patients with systemic sclerosis. Lancet, ii, 453.

MARTIN, M.F.R., Dowd, P.M., RING, E.F.J., CoOK, E.D., DIEPPE, P.A. \& KIRBY, J.D.T. (1980) Prostaglandin $E_{1}$ in the treatment of systemic sclerosis. Annals of the Rheumatic Diseases, 39, 44.

WANG, T., SHePPARD, J.R. \& Foder, J.E. (1978) Rise and fall of cyclic AMP required for outset of lymphocyte DNA synthesis. Science, 201, 155.

(Accepted 28 October 1982) 